\title{
Characterization of fat mixtures with diesel combustion and process combustion fireplace at constant pressure
}

\author{
J. F. José Alonso ${ }^{(1)}$, J.A.López Sastre ${ }^{(2)}$, C. Romero-Ávila ${ }^{(2)}$ \\ (1) Departamento de Ingeniería Energética y Fluidomecánica \\ Escuela Técnica Superior de Ingenieros Industriales, Universidad de Valladolid. \\ Paseo del Cauce s/n, 47014, Valladolid. \\ Phone/Fax number: +0034 983 423363, e-mail: julsan@eis.uva.es \\ (2) Departamento de Química Orgánica. \\ Escuela Técnica Superior de Ingenieros Industriales, Universidad de Valladolid. \\ Paseo del Cauce s/n, 47014, Valladolid.
}

\begin{abstract}
This article studies the characteristics of fatty pork and animal by-products not intended for human consumption (in Spain SANDACH). We assess category 1 and 3 and mixtures thereof with diesel for use as fuel in a combustion chamber at constant pressure which has a mechanical pulverization burner pressure and emulsion.
\end{abstract}

Characterization of fats and their blends with diesel fuel was based on four criteria: i) intrinsic chemical quality (composition of elements and ash), ii) mechanical quality (viscosity, density for different temperatures), iii) energy quality (calorific value) and iv) the mixing process of various fats with diesel.

Finally, we conduct a study of possible technologies for use in a combustion process in a constant pressure chamber and we perform tests using a mechanical pulverization burner and burner pressure emulsion.

\section{Key words}

Fat characterization, mixtures, combustion process.

\section{Introduction}

Mad cow disease, or bovine spongiform encephalopathy (BSE), is a disease caused by prions which can be transmitted to humans through the consumption of infected animal parts, especially nerve tissues. On 3 October 2002, the EU adopted EC Regulation 1774/2002 on animal by-products not intended for human consumption (in Spain, SANDACH). The regulations establish animal and public health standards for the collection, transport, storage, handling, processing and use or disposal of such products.

Table 1 shows to transformed animal fat production in Castilla y León (the largest region in Spain, most of which is agriculture and livestock land), mainly with regard to production at certain slaughterhouses and cutting plants. This information classifies to transformed category animal fat into the three categories in line with EC Regulation 1774/2002.

Table 1. SANDACH production in slaughterhouses in Castilla y

\begin{tabular}{|l|c|c|c|}
\hline \multirow{2}{*}{ Lategory } & \multicolumn{3}{|c|}{ By-products $(\mathrm{kg})$} \\
\cline { 2 - 4 } & 2005 & 2006 & 2007 \\
\hline Category 1 & $14,244.915$ & $15,431.362$ & $15,876.491$ \\
\hline Category 2 & $39,287.700$ & $40,197.102$ & $38,192.050$ \\
\hline Category 3 & $120,065.405$ & $139,360.633$ & $144,870.704$ \\
\hline
\end{tabular}

As can be seen for 2007, total to transformed animal fat production in Castilla y León was around 200000 tons, of which approximately $73 \%$ correspond to category 3, $20 \%$ to category 2 and the remaining $7 \%$ to category 1 , according to data issued by the Health Protection and Food Safety Agency at the Regional Health Ministry, in the Regional Government of Castilla y León.

\section{Characterization of animal fats and diesel as fuel}

Characterization of pork fat (referred to as PR), in to transformed category 1 animal fat (referred to as CU) and to transformed category 3 animal fat (referred to as CT), and diesel, the characterization was carried out at the Castilla y León Regional Fuel Laboratory (LARECOM). Table 2 shows the main characteristics.

The characteristics of the various substances, shown in Table 2, evidence how the three kinds of fats (PR, CU, $\mathrm{CT}$ ) display quite similar characteristics. The main differences with regard to diesel concern factors such as viscosity and percentage of oxygen. We conclude that due to viscosity a specific burner should be used for the combustion process. As regards oxygen, a lower air flow should be used. 
Table 2: Characteristics of Pr, CU, CT and Diesel.

\begin{tabular}{|l|c|c|c|c|}
\hline & PR Fat & CU Fat & CT Fat & Diesel \\
\hline Density at $15^{\circ} \mathrm{C}\left(\mathrm{kg} / \mathrm{m}^{3}\right)$ & 911 & 916 & 910 & 848 \\
\hline Density at $35^{\circ} \mathrm{C}\left(\mathrm{kg} / \mathrm{m}^{3}\right)$ & 899 & 904 & 898 & 635 \\
\hline Kinematic Viscosity at $40^{\circ} \mathrm{C}\left(\mathrm{mm}^{2} / \mathrm{s}\right)$ & 40.87 & 51.97 & 41.64 & 2.7 \\
\hline Kinematic Viscosity at $100^{\circ} \mathrm{C}\left(\mathrm{mm}^{2} / \mathrm{s}\right)$ & 8.46 & 9.06 & 8.64 & 1.2 \\
\hline S percent by mass & 0.03 & 0.04 & 0.03 & 0.07 \\
\hline C percent by mass & 76.8 & 75.1 & 75.1 & 86.6 \\
\hline H percent by mass & 11.6 & 11.6 & 11.7 & 12.3 \\
\hline O percent by mass & 11.3 & 12.9 & 13.0 & 1.03 \\
\hline N percent by mass & 0.2 & 0.16 & 0.05 & ---- \\
\hline Ashes & 0.002 & 0.164 & 0.002 & --- \\
\hline P.C.S. $(\mathrm{kcal} / \mathrm{kg})$ & 9425 & 9277 & 9333 & 10735 \\
\hline P.C.I. $(\mathrm{kcal} / \mathrm{kg})$ & 8837 & 8689 & & 8740 \\
\hline
\end{tabular}

\section{Characterization of animal fat mixtures and diesel as fuel}

Each sample is labelled with an identification code, consisting of two letters and two numbers:

\section{PR-00 CU-00 CT-00}

- The letters PR refer to edible pork fat, the letters CU to transformed category 1 animal fat, and the letters CT to transformed category 3 animal fat.

- The numbers represent the percentage (\%) of fat used in the mixture.
Four mixtures are prepared for each type of fat, using different percentages $(10,20,30$ and $40 \%)$.

Tables 3, 4 and 5 show the characteristics of each of the mixtures. Determining the characteristics of the mixtures is obtained: i) from other known properties (derivatives). ii) from a (theoretical) knowledge of said properties in the pure components that make up the mixture and iii) from (empirical) laboratory measurements such as the viscosity of each of the mixtures determined in the laboratory.

Table 3. Characteristics of the mixtures of transformed category 1 animal fat and diesel.

\begin{tabular}{|c|c|c|c|c|c|c|c|}
\hline Name & $\% \mathrm{C}$ & $\% \mathbf{H}$ & $\% \mathrm{O}$ & $\% \mathrm{~S}$ & $\begin{array}{l}\text { Density } \\
\left(15^{\circ} \mathrm{C}\right)\end{array}$ & $\begin{array}{l}\text { Viscosity } \\
\left(100^{\circ} \mathrm{C}\right)\end{array}$ & L.H.V \\
\hline CU-10 & 85.45 & 12.24 & 2.23 & 0.07 & 854.8 & 1.36 & 9969.7 \\
\hline CU-20 & 84.30 & 12.16 & 3.40 & 0.06 & 861.6 & 1.64 & 9827.4 \\
\hline CU-30 & 83.15 & 12.09 & 4.59 & 0.06 & 868.4 & 1.95 & 9685.1 \\
\hline CU-40 & 82.00 & 12.02 & 5.78 & 0.05 & 875.2 & 2.44 & 9542.8 \\
\hline CU-50 & 80.85 & 11.95 & 6.965 & 0.06 & 882.0 & 3.13 & 9400.5 \\
\hline
\end{tabular}

Table 4. Characteristics of the mixtures of transformed category 3 animal fat and diesel.

\begin{tabular}{|c|c|c|c|c|c|c|c|}
\hline Name & $\% \mathrm{C}$ & $\% \mathbf{H}$ & $\% 0$ & $\% \mathrm{~S}$ & $\begin{array}{l}\text { Density } \\
\left(15^{\circ} \mathrm{C}\right) \\
\end{array}$ & $\begin{array}{l}\text { Viscosity } \\
\left(100^{\circ} \mathrm{C}\right)\end{array}$ & L.H.V \\
\hline CT-10 & 85.45 & 12.24 & 2.23 & 0.06 & 860.3 & 1.38 & 9974.8 \\
\hline CT-20 & 84.30 & 12.18 & 3.42 & 0.06 & 860.4 & 1.60 & 9837.6 \\
\hline CT-30 & 83.15 & 12.12 & 4.62 & 0.06 & 866.6 & 1.89 & 9700.4 \\
\hline CT-40 & 82.00 & 12.06 & 5.82 & 0.05 & 872.8 & 2.48 & 9563.2 \\
\hline CT-50 & 80.85 & 12.00 & 7.02 & 0.05 & 879.0 & 3.10 & 9426.0 \\
\hline
\end{tabular}

Table 5. Characteristics of the mixtures of pork fat and diesel.

\begin{tabular}{|c|c|c|c|c|c|c|c|}
\hline Name & \%C & \%H & \%O & \%S & $\begin{array}{c}\text { Density } \\
\left(\mathbf{1 5}^{\mathbf{~}} \mathbf{C}\right)\end{array}$ & $\begin{array}{c}\text { Viscosity } \\
\left(\mathbf{1 0 0}^{\mathbf{~}} \mathbf{C}\right)\end{array}$ & L.H.V. \\
\hline PR-10 & 85.62 & 12.23 & 2.06 & 0.06 & 854.3 & 1.36 & 9984.5 \\
\hline PR-20 & 84.64 & 12.16 & 3.08 & 0.06 & 860.6 & 1.62 & 9857 \\
\hline PR-30 & 83.66 & 12.09 & 4.11 & 0.06 & 866.9 & 2.07 & 9729.5 \\
\hline PR-40 & 82.68 & 12.02 & 5.14 & 0.05 & 873.2 & 2.45 & 9602.0 \\
\hline PR-50 & 81.70 & 11.95 & 6.17 & 0.05 & 879.5 & 3.12 & 9474.5 \\
\hline
\end{tabular}

To characterize a fuel obtained from a mixture of fat and diesel, in addition to the previously mentioned features, the characterization of the dissolution process of the fats in diesel also needs to be known. This provides us with a knowledge of the kind of mixture as well as the characteristics linked to the type of mixture such as the presence of paraffins or crystals which might affect the combustion process and/or the installation's feeding systems (pumps, nozzles, burner, filters, etc.).

In general terms, the mixtures are classified into homogeneous and heterogeneous mixtures. Homogeneous mixtures optimally display a single stage and even distribution of their physical-chemical properties. Heterogeneous mixtures display two or more stages and an uneven distribution of their properties. The 
burner technology used in this study requires a homogeneous mixture. For this reason we conduct a study of the dissolution of the mixture in fat in diesel.

The studies carried out for the various types of fat (PR, $\mathrm{CU}$ and $\mathrm{CT}$ ) and the different percentages of mixtures $(10,20,30$ and $40 \%)$ lead us to conclude that for combustion of the mixtures animal fats and diesel mixtures need to be heated and stirred in order to obtain a homogeneous mixture.

The mixture must reach a temperature of $38{ }^{\circ} \mathrm{C}$ and be stirred constantly. This produces a homogeneous mixture and prevents formation of crystals which might cause problems in filters and nozzles. Figure1.
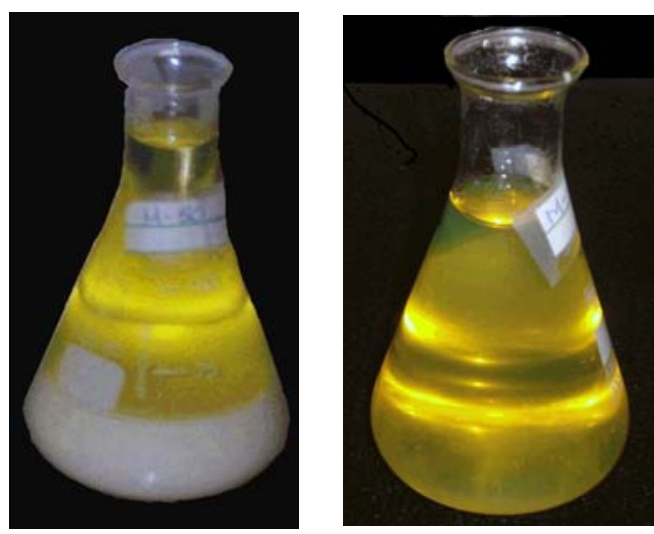

Fig. 1: Homogeneous and heterogeneous mixtures.

\section{Experimental Design}

The factors to be analysed in the experimental design chosen, as well as the various levels thereof, are those which can be controlled in the experimental device: type of fat, percentage of fat in the mixture, supply pressure and air flow.

Once these factors and their corresponding levels have been determined, the test matrix is posited, making sure that all the levels of all the factors will be tested with all the levels of the other factors the same number of times, in other words ensuring orthogonality.

Table 6 shows the factors and their corresponding levels:

Table 6: Test matrix carried out.

\begin{tabular}{|l|l|l|l|}
\hline $\begin{array}{l}\text { Type of } \\
\text { fat }\end{array}$ & \% fat & P supply & Q air \\
\hline CU & $10 \%$ & $10 \mathrm{bar}$ & $2.6 \mathrm{~m}^{3} / \mathrm{h}$ \\
\hline CT & $20 \%$ & $12 \mathrm{bar}$ & $5 \mathrm{~m}^{3} / \mathrm{h}$ \\
\hline PR & $30 \%$ & $14 \mathrm{bar}$ & $7.5 \mathrm{~m}^{3} / \mathrm{h}$ \\
\cline { 2 - 4 } & $40 \%$ & \multicolumn{2}{|c}{} \\
\cline { 2 - 3 } & &
\end{tabular}

The tests will therefore be carried out in the following order:

- Using the type of fat.

- Preparing the diesel mixtures with the different proportions of fat.
- For a single sample of a type of fat at a specific percentage, varying the supply pressure.

- For a single sample of a type of fat at a specific percentage, testing with various air flow levels for each level of supply pressure.

The number of tests to be carried out to ensure orthogonality must coincide with the product of the number of levels of all the factors:

$$
3 \times 4 \times 3 \times 3=108 \text { tests }
$$

\section{Experimental Facility}

The energy generating group is made up of a conventional house-heating boiler and burner, whose characteristics are shown in Table 7.

Table 7: Characteristics of the generating group used in the combustion tests.

\begin{tabular}{|c|c|c|c|c|}
\hline \multicolumn{5}{|c|}{ Boiler model AR/25GT by ROCA } \\
\hline \multicolumn{4}{|c|}{ Boiler type } & Cast iron \\
\hline \multicolumn{4}{|c|}{ Calorific power } & $26.7 \mathrm{~kW}$ \\
\hline \multicolumn{4}{|c|}{ Water capacity } & 26 litres \\
\hline \multicolumn{4}{|c|}{ Approximate weight } & $210 \mathrm{~kg}$ \\
\hline \multicolumn{4}{|c|}{ Max. working temperature } & $110^{\circ} \mathrm{C}$ \\
\hline \multicolumn{5}{|c|}{ Burner model KADET-TRONIC by ROCA } \\
\hline $\begin{array}{l}\text { GPH } \\
\text { Nozzle }\end{array}$ & Angle & $\begin{array}{l}\text { Pump } \\
\text { pressure } \\
\text { (bar) }\end{array}$ & $\begin{array}{l}\text { Flow } \\
(\mathrm{l} / \mathrm{h})\end{array}$ & $\begin{array}{l}\text { Regulation } \\
\text { of air }\end{array}$ \\
\hline 0.5 & $60^{\circ}$ & $8-16$ & 2.3 & \\
\hline
\end{tabular}

The control parameters of the facility are indicated in Table 8. These values should be maintained within a certain range for the experiment to be considered stationary.

Table 8: Control parameters of the facility

\begin{tabular}{|l|l|}
\hline $\begin{array}{l}\mathrm{T}_{\text {input }} \\
\left({ }^{\circ} \mathrm{C}\right)\end{array}$ & $\begin{array}{l}\text { Represents the water temperature in the } \\
\text { distributor situated in the input circuit }\end{array}$ \\
\hline $\begin{array}{l}\mathrm{T}_{\text {returning }} \\
\left({ }^{\circ} \mathrm{C}\right)\end{array}$ & $\begin{array}{l}\text { Indicates the water temperature in the return } \\
\text { tank, through which all the water flows } \\
\text { before returning to the boiler }\end{array}$ \\
\hline $\begin{array}{l}\mathrm{P}_{\text {impulse }} \\
\text { bar })\end{array}$ & $\begin{array}{l}\text { Water pressure in the main circuit impulse, } \\
\text { immediately prior to the distributor. }\end{array}$ \\
\hline $\begin{array}{l}\mathrm{P}_{\text {aspiration }} \\
\text { bar) }\end{array}$ & $\begin{array}{l}\text { Water pressure in the aspiration of the water } \\
\text { pump situated before entry into the } \\
\text { distributor. }\end{array}$ \\
\hline $\begin{array}{l}\mathrm{P}_{\text {impulse fuel }} \\
(\text { bar })\end{array}$ & Impulse pressure in the fuel pump. \\
\hline $\begin{array}{l}\mathrm{P}_{\text {aspiration fuel }} \\
(\mathrm{mm} \mathrm{Hg})\end{array}$ & Aspiration pressure in the fuel pump \\
\hline $\begin{array}{l}\mathrm{T}_{\text {fuel }} \\
\left({ }^{\circ} \mathrm{C}\right)\end{array}$ & Temperature of the fuel situated in the tank. \\
\hline $\begin{array}{l}\mathrm{T}_{\text {boiler }} \\
\left({ }^{\circ} \mathrm{C}\right)\end{array}$ & $\begin{array}{l}\text { Temperature of the water passing through } \\
\text { the boiler. }\end{array}$ \\
\hline $\begin{array}{l}\mathrm{T}_{\text {ambient }} \\
\left({ }^{\circ} \mathrm{C}\right)\end{array}$ & Ambient temperature. \\
\hline
\end{tabular}

The characteristics of the fume analyser used to measure the combustion conditions are shown in Table 9.

Table 9: Measuring equipment used in the experiment, with measurement range.

\begin{tabular}{|l|l|}
\hline \multicolumn{2}{|l|}{ Fume analyser (one piece) } \\
\hline $\begin{array}{l}\text { Make and model } \\
\text { K type thermometer }\end{array}$ & TESTO model $342-3$ \\
Range -40 to $1,200^{\circ} \mathrm{C} \pm 0.1^{\circ} \mathrm{C}$ \\
\hline
\end{tabular}




\begin{tabular}{|l|l|}
\hline $\begin{array}{l}\text { Electrochemical } \mathrm{O}_{2} \text { drill } \\
\text { CO drill (with } \mathrm{H} \text { compens.) } \\
\text { NO electrolytic cell drill }\end{array}$ & $\begin{array}{l}\text { Range } 0 \% \text { to } 21 \% \\
\text { Range } 0 \text { to } 4,000 \mathrm{ppm} . \\
\text { Range } 0 \text { to 3,000 ppm }\end{array}$ \\
\hline Temperature drill (Five drills) \\
\hline Thermopar type & $\mathrm{K}$ \\
Measurement range & $-40^{\circ}$ to $1,000^{\circ} \mathrm{C} \pm 0.5^{\circ} \mathrm{C}$ \\
\hline Pressure drill (Four drills) \\
\hline Manometer type & Spiral \\
Impulse pressure range & 1 to 40 bar accuracy to $1 \%$ \\
Aspiration pressure range & 0.2 to 1 bar accuracy to $1 \%$ \\
\hline
\end{tabular}

\section{6 - Experimental results}

Combustion of the three types of fats mixed in different percentages with diesel, varying the supply pressure and combustion air-flow proved possible in all cases, yielding $\mathrm{CO}$ and $\mathrm{NO}_{\mathrm{x}}$ emission values below the legal limits, the combustion energy efficiency of the mixtures being slightly above diesel combustion. Table 10 shows all the results obtained for SANDACH category 3 fat mixed at $40 \%$.

Table 10: Results of CT fat combustion.

\begin{tabular}{|c|c|c|c|c|}
\hline \multirow{4}{*}{ Mixture } & $\begin{array}{c}\text { Inject. } \\
\text { pressure } \\
\text { (bar) }\end{array}$ & $\begin{array}{c}\text { Air- } \\
\text { flow } \\
\left(\mathrm{m}^{3} / \mathrm{h}\right)\end{array}$ & $\begin{array}{c}\mathrm{CO} \\
(\mathrm{ppm})\end{array}$ & $\begin{array}{c}\mathrm{NO}_{\mathrm{x}} \\
(\mathrm{ppm})\end{array}$ \\
\hline \multirow{4}{*}{ CT-40 } & \multirow{3}{*}{10} & 2.6 & 62 & 29 \\
\cline { 3 - 5 } & \multirow{3}{*}{12} & 5.0 & 52 & 28 \\
\cline { 3 - 5 } & & 7.5 & 70 & 27 \\
\cline { 3 - 5 } & \multirow{3}{*}{14} & 2.6 & 36 & 31 \\
\cline { 3 - 5 } & & 5.0 & 36 & 30 \\
\cline { 3 - 5 } & & 2.5 & 50 & 29 \\
\cline { 3 - 5 } & & 5.0 & 28 & 33 \\
\cline { 3 - 5 } & & 7.5 & 32 & 32 \\
\hline
\end{tabular}

CO emissions fall when supply pressure is increased although no clear trend is observed with air-flow. This result is due to the enhanced pulverization of the fuel in the combustion chamber when pressure is increased. The increase in the viscosity of the mixtures enhances the combustion process. Figure 2 shows the evolution of the CO ppm in the combustion fumes of mixture CT30, in terms of the supply pressure and air flow.

$\mathrm{NO}_{\mathrm{x}}$ emissions increase as supply pressure increases and excess air decreases. This is due to the increase in flame temperature as the combustion process improves and excess air falls. Figure 3 shows the evolution of the $\mathrm{NO}_{\mathrm{x}}$ ppm in the combustion fumes of mixture CT30, in terms of the supply pressure and air flow.

CO emissions with regard to the percentage of the mixture do not evidence any significant influence when the supply pressure is 14 bars. CO increases with an excess of combustion air. This is due to the kind of burner used, which suffers flame detachment. Figure 4 shows the evolution of the CO ppm in the fumes, when the mixture is injected at 14 bars, for different percentages of mixtures and three combustion air-flows.

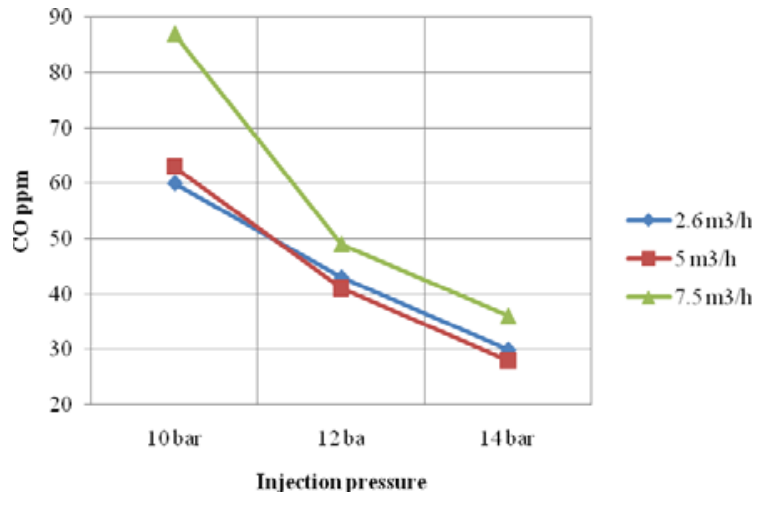

Fig. 2: Evolution of $\mathrm{CO}$ in type CT30 mixture combustion.

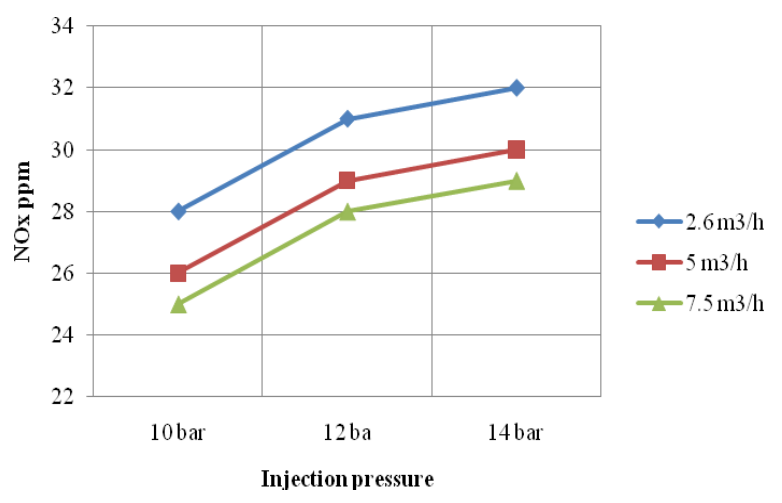

Fig. 3: Evolution of $\mathrm{NO}_{\mathrm{x}}$ in type CT30 mixture combustion.

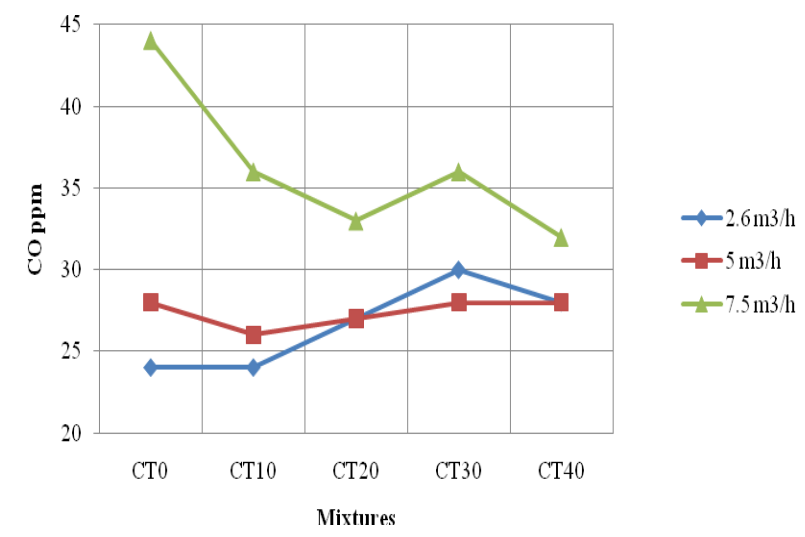

Fig. 4: Evolution of CO in the combustion of various CT mixtures.

\section{Conclusion}

Mixtures of animal fat and diesel were successfully burned in a conventional facility, without the need for the fat to be treated, as a result of which the two aims set out in the study have been achieved: a) Energy re-use of an abundant waste source, b) To evidence that existing diesel facilities may be used, a preheated tank and stirring of the mixture being required.

The fat used is an animal by-product transformed by a livestock waste handling facility, as it is brought into the installation, meaning that abundant waste is available and requires no transformation. 
The mixing tank must preheat the mixture to a temperature of $38^{\circ} \mathrm{C}$, the temperature at which the mixture offers the most homogenous characteristics. The mixture must also be stirred to avoid silting due to differences in density.

Conventional diesel facilities offer two adjustable parameters: supply pressure and air flow. In the current work we present the pre-established values to obtain optimum combustion.

Future studies will address the use of other kinds of burners, which may use fuels with higher viscosities so as to burn fats without the need to mix with diesel.

\section{References}

[1] López Sastre, J.A., San José Alonso, J, Romero-Ávila García, C., López Romero-Ávila, E.J., and Rodriguez Alons, C., "A study of the decrease in fossil CO2 emissions of energy generation by using vegetable oils as combustible”, Building and Environment, 38 (2003) 129133.

[2] López Sastre, J.A., San José Alonso, J, Romero-Ávila García, C., López Romero-Ávila, E.J., "Using mixtures of diesel and sunflower oil fuel for heating purposes in Castilla y León”, Energy 30 (2005) 573-582.

[3] López Sastre, J.A., San José Alonso, J, Romero-Ávila García, C., López Romero-Ávila, E.J., “Combustion of rapeseed oil and diesel oil mixtures for use in the production of heat energy”, Fuel Processing Technology 87 (2006) 97-102.

[4] San José Alonso, J, López Sastre, J.A., Romero-Ávila García, C., López Romero-Ávila, E.J., “Combustion of soya oil and diesel oil mixtures for use in thermal energy production”, Energy \& Fuels, 22 (2008) 3513-3516.

[5] San José Alonso, J, López Sastre, J.A., San José Alonso, J, Romero-Ávila García, C., López RomeroÁvila, E.J., "A note on the combustion of blends of diesel and soya, sunflower and rapeseed vegetable oils in a light boiler", Biomass-Bioenergy, 32 (2008) 880-886. 